OPEN ACCESS

Edited by:

Michael Heinrich,

UCL School of Pharmacy,

United Kingdom

Reviewed by:

Eleni Skaltsa,

National and Kapodistrian University

of Athens, Greece

Pinarosa Avato,

Università degli Studi di Bari Aldo

Moro, Italy

*Correspondence:

Baojun Xu

baojunxu@uic.edu.hk

Specialty section:

This article was submitted to

Ethnopharmacology,

a section of the journal

Frontiers in Pharmacology

Received: 30 April 2017 Accepted: 13 September 2017

Published: 27 September 2017

Citation:

Liu R, Zheng Y, Cai Z and Xu B

(2017) Saponins and Flavonoids from Adzuki Bean (Vigna angularis L.) Ameliorate High-Fat Diet-Induced Obesity in ICR Mice.

Front. Pharmacol. 8:687. doi: 10.3389/fphar.2017.00687

\section{Saponins and Flavonoids from Adzuki Bean (Vigna angularis L.) Ameliorate High-Fat Diet-Induced Obesity in ICR Mice}

\author{
Rui Liu',2, Yinan Zheng ${ }^{3}$, Zongwei Cai ${ }^{2}$ and Baojun $\mathrm{Xu}^{1 *}$ \\ ${ }^{1}$ Food Science and Technology Program, Beijing Normal University-Hong Kong Baptist University United International \\ College, Zhuhai, China, ${ }^{2}$ Department of Chemistry, Hong Kong Baptist University, Kowloon Tong, China, ${ }^{3}$ College of \\ Chinese Medicinal Materials, Jilin Agricultural University, Changchun, China
}

Background and purpose: As an herbal medicine, adzuki bean has been practiced since the Tang Dynasty of China to maintain health and control weight; this practice is still very popular in China nowadays. However, it is still lack of sufficient scientific basis to explain scientific principle of this popular civil practice in weight control using adzuki bean. The purpose of this study was to verify and explain the anti-obesity effects of adzuki bean through in vitro enzymatic assays, in vitro lipolysis and in vivo study of obese mice model.

Methods: Inhibitory effects of flavonoids and saponins from adzuki bean (Vigna angularis) on pancreatic lipase, $\alpha$-glucosidase activities, and noradrenaline-induced lipolysis were assessed. High-fat diet-induced obesity model was created to study antiobesity effects of adzuki bean. Both serum and liver lipid parameters were determined after 8 weeks intervention.

Results: Adzuki bean extracts enhanced lipolysis. Compared to the final body weight of high-fat diet group, oral administration of adzuki bean significantly $(p<0.05)$ reduced the final body weight of mice and adipose tissue accumulation. The adzuki bean intervention also significantly reduced the levels of serum triglyceride, total cholesterol, low density lipoprotein-cholesterol, and liver lipid.

Conclusion: Adzuki bean demonstrated the anti-obesity effects on mice, such effects may mediated through the inhibitory effects of flavonoids and saponins from adzuki bean on $\alpha$-glucosidase and pancreatic lipase activities, and lipolysis enhancement effect of active components from adzuki bean.

Keywords: adzuki bean, pancreatic lipase, lipolysis, obese mice, adipose tissue

\section{INTRODUCTION}

Overweight and obesity are defined by World Health Organization (WHO) as abnormal or excessive fat accumulation that presents a risk to health. It was reported that one billion adults were overweight, while more than 300 million were obese in the world in 2010 (WHO, 2010). Overweight and obesity lead to many serious diseases, such as high blood pressure, diabetes, 
strokes, cancers (Kushner, 2002; Festi et al., 2004; Nammi et al., 2004; WHO, 2010). Overweight and obesity are becoming a major public health issue globally.

Unhealthy diet is one of the major risk factors for chronic diseases like obesity and diabetes. It is widely accepted that dietary fat intake was directly or indirectly related to the occurrence of obesity, diabetes, high cholesterol, and other diseases (Hill et al., 2000). Consumption of bioactive compounds from diet or intake of dietary supplementation is one of possible ways to control obesity and to prevent or reduce the risks of developing various obesity-related diseases.

Food legumes are widely consumed by most nations, especially Asian countries like China. Saponins and phenolics from food legumes have been reported to possess many biological activities such as anti-inflammatory (Zha et al., 2011), anti-cancer (Zhang and Popovich, 2010), and anti-hypertension (Takahashi et al., 2008). Adzuki bean is mainly produced and consumed in China and several other countries in East Asia. It has been used as traditional Chinese herbal medicine and food for over thousands of years. The bioactivities, such as anti-tumor (Itoh et al., 2002, 2005), anti-diabetes (Itoh et al., 2004, 2009), and antioxidant (Wu et al., 2004; Yao et al., 2011a; Sreerama et al., 2012; Xu and Chang, 2012) have been documented previously.

"Eating beans to lose weight" has been practiced since the Tang Dynasty of China; currently "eating beans to lose weight" is still very popular folk practice in China, Japan, and South Korea. However, reports on health benefits of adzuki bean in obesity prevention or weight control are limited. It is still lack of sufficient scientific basis to explain scientific principle of these popular civil practices in weight control using adzuki bean. Therefore, the purpose of this study was to explain the anti-obesity effects of adzuki bean through in vitro enzymatic assays, in vitro lipolysis, and in vivo study of obese mice.

\section{MATERIALS AND METHODS}

\section{Materials}

Adzuki beans (Vigna angularis L.) were purchased from local market in Changchun, Jilin Province, and identified by Prof. Jinming $\mathrm{Mu}$ of Faculty of Agronomy in Jilin Agricultural University. Triolein, taurocholic acid sodium salt hydrate, $\mathrm{N}$ [Tris (hydroxymethyl) methyl]-2-aminopropanesulfonic acid (TES) buffer, phosphatidylcholine, porcine pancreatic lipase, $\alpha$-glucosidase, and $p$-nitrophenyl- $\alpha$-glucopyranoside were purchased from Sigma (St. Louis, MO, United States). Lipid assay kits for testing triglycerides (TG), total cholesterol (TC), high density lipoprotein-cholesterol (HDL-C), and low density lipoprotein-cholesterol (LDL-C), were purchased from Biosino Bio-technology and Science Inc. (Beijing, China). Other chemicals, such as sodium dihydrogen phosphate dehydrate, disodium hydrogen phosphate dodecahydrate, were of analytical grade. Macroporous adsorptive resins AB-8 was supplied by Nankai University, and polyamide resin was purchased from Sinopharm Chemical Reagent Co., Ltd. (Beijing, China).

\section{Experimental Animals}

Female ICR mice, 3 weeks old, were obtained from the Experimental Animal Holding Center of Jilin University, and housed individually in plastic cages in a $12 / 12 \mathrm{~h}$ light/dark cycle in a temperature- and humidity-controlled room for 1 week adaptation. The animals were allowed to access food and water freely. The healthy ones were used for further antiobesity study. Young male Wistar rats (5 weeks old) were also obtained from the Experimental Animal Holding Center of Jilin University, which were utilized to carry out the in vitro lipolysis experiments. The Animal Care and Use Committee of Jilin Agricultural University approved all experimental procedures. This study was conducted according to the National Research Council's Guide for the Care and Use of Laboratory Animals.

\section{Diets for ICR Mice}

Both normal diet (ND) and high-fat diet (HFD) were purchased from the feed center of the Experimental Animal Holding Center of Jilin University (Changchun, China). ND consisted of 5\% fat, $53 \%$ carbohydrate, $23 \%$ protein, and total calorific value $25 \mathrm{~kJ} / \mathrm{kg}$. HFD consisted of $22 \%$ fat, $48 \%$ carbohydrate, and $20 \%$ protein, and total calorific value $44.3 \mathrm{~kJ} / \mathrm{kg}$. The diets were stored at $-20^{\circ} \mathrm{C}$ and prepared freshly each day to avoid auto-oxidation of lipids.

\section{Preparation of Flavonoids and Saponins from Adzuki Bean}

Flavonoids of adzuki bean (ABF) and saponins of adzuki bean (ABS) were prepared according to the previous articles (Jia and Lu, 2008; Itoh and Furuichi, 2009). Briefly, adzuki bean was ground and $14 \mathrm{~kg}$ of the powder was then extracted with $140 \mathrm{~L}$ of $70 \%$ ethanol for three times. The combined extract solution was filtrated and concentrated to remove ethanol. The remaining aqueous solution was extracted with $14 \mathrm{~L}$ of petroleum ether at room temperature for three times. The aqueous phase was then extracted with $14 \mathrm{~L}$ of $n$-butanol at room temperature three times. The $n$-butanol solution was evaporated under vacuum to obtain $158.6 \mathrm{~g}$ of $n$-butanol extract which was total extract of adzuki bean (ABTE). The crude flavonoids were collected in the $45 \%$ ethanol fraction from AB-8 resin column after eluting with water. The collected ABF were subjected to the second column with polyamide according to the literatures ( $\mathrm{Wu}$ et al., 2009; Wei et al., 2011), and the enriched flavonoid was further obtained in $40 \%$ ethanol fraction after eluting with $10 \%$ ethanol from polyamide column. ABF was obtained from the supernatant after precipitating with methanol-acetone finally. The enriched ABS was collected in the $80 \%$ ethanol fraction after eluting with $45 \%$ ethanol by AB- 8 resin column. With further precipitation method, $A B S$ was precipitated by the reagents of methanol-acetone. The chemical constituents of ABTE, ABF, and ABS were identified by liquid chromatography-ion trap mass spectrometry. Quantitative analysis was performed on an Agilent 1100 series HPLC system. The contents of saponins and flavonoids were reported in our latest publication (Liu et al., 2017). 


\section{$\alpha$-Glucosidase Activity Assay}

$\alpha$-Glucosidase inhibitory activity of adzuki bean was investigated according to the method of Kwon et al. (2008). Briefly, a volume of $50 \mu \mathrm{L}$ of different concentrations of sample solutions and $100 \mu \mathrm{L}$ of $0.1 \mathrm{M}$ phosphate buffer ( $\mathrm{pH}$ 6.9) containing $\alpha$-glucosidase solution $(1.0 \mathrm{U} / \mathrm{mL})$ were incubated in a 96 -well plate at $25^{\circ} \mathrm{C}$ for $10 \mathrm{~min}$. After pre-incubation, $50 \mu \mathrm{L}$ of $5 \mathrm{mM} p$-nitrophenyl- $\alpha$-D-glucopyranoside solution in $0.1 \mathrm{M}$ phosphate buffer ( $\mathrm{pH}$ 6.9) was added to each well at $5 \mathrm{~s}$ intervals. The reaction mixtures were incubated at $25^{\circ} \mathrm{C}$ for $5 \mathrm{~min}$. Absorbance readings were recorded at $405 \mathrm{~nm}$ by a microplate reader (FLUOstar Omega 415-1179, BMG LABTECH GmbH, Germany), and the absorbance of a control which contained $50 \mu \mathrm{L}$ of buffer solution instead of the extract was recorded under the same experimental conditions. The \% inhibition of $\alpha$-glucosidase activity was calculated as the following equation:

$$
\% \text { Inhibition }=\left(\frac{A_{405}^{\text {Control }}-A_{405}^{\text {Sample }}}{A_{405}^{\text {Control }}} \times 100\right) .
$$

\section{Pancreatic Lipase Activity Assay}

Lipase activity was determined according to the previous articles (Zapf et al., 1981; Tsujita and Okuda, 1983) with a slight modification. A suspension of triolein $80 \mathrm{mg}$, phosphatidylcholine $10 \mathrm{mg}$, and taurocholic acid $5 \mathrm{mg}$ in $9 \mathrm{~mL}$ of $0.1 \mathrm{M}$ TES buffer ( $\mathrm{pH} 7.0$ ) containing $0.1 \mathrm{M} \mathrm{NaCl}$ was sonicated for $10 \mathrm{~min}$ by a KQ $5200 \mathrm{DE}$ ultrasonic equipment (Kunshan Ultrasonic Instruments Co., Ltd, Jiangsu, China). This sonicated substrate suspension $10 \mu \mathrm{L}$ was incubated with $50 \mu \mathrm{L}$ of pancreatic lipase and $100 \mu \mathrm{L}$ of various concentrations of chondroitin sulfate solution for $30 \mathrm{~min}$ at $37^{\circ} \mathrm{C}$ in a final volume of $250 \mu \mathrm{L}$. The incubation mixture was added into $3 \mathrm{~mL}$ aliquots of a 1:1 (v/v) mixture of chloroform and $n$-heptane containing $2 \%$ $(\mathrm{v} / \mathrm{v})$ methanol and extracted by shaking the tubes horizontally for $10 \mathrm{~min}$ by a vortex (XK96-A, Xinkang Medical Apparatus Co., Ltd., Jiangsu, China). The mixture was centrifuged at $3000 \mathrm{rpm}$ for $10 \mathrm{~min}$ (TG16-WS centrifuge, Hunan, China), and the upper aqueous phase was removed by suction. Copper reagent $(1 \mathrm{~mL})$ was then added to the lower organic phase. The tube was shaken for $10 \mathrm{~min}$, the mixture was centrifuged at $3000 \mathrm{rpm}$ for $10 \mathrm{~min}$, and then $1.5 \mathrm{~mL}$ of the upper organic phase, which contained copper salts of the extracted free fatty acids, was treated with $1.5 \mathrm{~mL}$ of $0.1 \%(\mathrm{w} / \mathrm{v})$ bathocuproine in chloroform containing $0.05 \%(\mathrm{w} / \mathrm{v}) 3(2)$-tert-butyl-4-hydroxyanisole. The absorbance was then measured at $480 \mathrm{~nm}$ by 722 -visible spectrophotometer (Shanghai, China). The \% inhibition of pancreatic lipase activity was calculated as the following equation:

$$
\% \text { Inhibition }=\left(\frac{A_{480}^{\text {Control }}-A_{480}^{\text {Sample }}}{A_{480}^{\text {Control }}} \times 100\right) .
$$

\section{Lipolysis Assay}

Young male Wistar rats (150-160 g) were given a standard laboratory ND and water freely. The rats were kept in a 12/12 h light/dark cycle in a temperature- and humidity-controlled room. Then the rats were killed by cervical dislocation and their epididymal adipose tissues were quickly collected. Fat cells were isolated from the epididymal adipose tissue according to a previous article (Rodbell, 1964). Briefly, the epididymal fat pads excluding the vascular were rinsed in Hank's buffer, and dried by filter paper. Thin distal portions from each epididymal fat pad were cut into several small pieces with scissors. Collagenase solution was added to the minced tissue pieces, and incubated at $37^{\circ} \mathrm{C}$ for $1 \mathrm{~h}$. After incubation, the tissue was dispersed into small fragments, and filtered. The filtrate was centrifuged at $1000 \mathrm{rpm}$, and finally the fat cells were collected from the upper layer.

The fat cell fraction was incubated for $1 \mathrm{~h}$ at $37^{\circ} \mathrm{C}$ in Hank's balanced solution ( $\mathrm{pH}$ 7.4) supplemented with $2.5 \%$ bovine serum albumin, noradrenaline, and the indicated amounts of tests. According to the previous article (Okuda et al., 1986), the release of free fatty acid was measured. Briefly, the incubation mixture $(250 \mu \mathrm{L})$ was mixed with $3 \mathrm{~mL}$ of chloroform- $n$-heptane $(1: 1, \mathrm{v} / \mathrm{v})$ containing $2 \%$ methanol and extracted by shaking the tube horizontally for $10 \mathrm{~min}$ in a shaker. The mixture was centrifuged at $3000 \mathrm{rpm}$ at $25^{\circ} \mathrm{C}$ for $5 \mathrm{~min}$, and the upper aqueous phase was removed by suction. Copper reagent $(1 \mathrm{~mL})$ was then added to the lower organic phase. Then the tube was shaken for $10 \mathrm{~min}$, the mixture was centrifuged at $3000 \mathrm{rpm}$ at $25^{\circ} \mathrm{C}$ for $10 \mathrm{~min}$, and $1.5 \mathrm{~mL}$ of the upper organic phase was treated with $1.5 \mathrm{ml}$ of $0.1 \%(\mathrm{w} / \mathrm{v})$ bathocuproine in chloroform containing $0.05 \%(\mathrm{w} / \mathrm{v}) 3(2)$-tert-butyl-4-hydroxyanisole. The absorbance was then measured at $480 \mathrm{~nm}$ by 722 -visible spectrophotometer (Shanghai, China). The effects of lipolytic relative to control and standard noradrenaline were calculated as the following equation:

$\%$ Lipolytic $=\frac{\left(A_{480}^{\text {Sample }}-A_{480}^{\text {Control }}\right)-\left(A_{480}^{\text {Standard }}-A_{480}^{\text {Control }}\right)}{A_{480}^{\text {Standard }}-A_{480}^{\text {Control }}} \times 100$.

\section{Estimation of Relative Parameters of Mice Fed with a High-Fat Diet}

After adaptation to the ND and the new life condition for 1 week, the healthy mice were randomly divided into eight groups (one normal group, seven HFD groups) according to the weight, of eight mice each group. The normal group was fed with ND and other seven groups were fed with a HFD for 4 weeks. Then the ND group was constantly fed with ND and the mice were orally administered physiological saline per day for additional 4 weeks. The HFD groups were treated with different ways for additional 4 weeks and were further divided into HFD group treated with physiological saline, HFD group orally administered with ABTE of $60 \mathrm{mg} / \mathrm{kg}$ per day (HFD + ABTE60), HFD group with ABTE of $300 \mathrm{mg} / \mathrm{kg}$ (HFD + ABTE300), HFD group with $\mathrm{ABF}$ of $60 \mathrm{mg} / \mathrm{kg}$ (HFD $+\mathrm{ABF} 60)$, HFD group with ABF of $300 \mathrm{mg} / \mathrm{kg}$ (HFD + ABF300), HFD group with ABS of $60 \mathrm{mg} / \mathrm{kg}$ $(\mathrm{HFD}+\mathrm{ABS} 60)$, and HFD group with ABS of $300 \mathrm{mg} / \mathrm{kg}$ $(\mathrm{HFD}+\mathrm{ABS} 300)$.

After 8 weeks of different treatments, blood was taken from each mouse by the artery and vein of fossa orbitalis (Liu et al., 2010). Then the blood was centrifuged at $4^{\circ} \mathrm{C}$ and the serum of each mouse was obtained and frozen at $-80^{\circ} \mathrm{C}$ until further analysis. Serum TG, TC, HDL-C, and LDL-C were determined 
using the lipid assay kits by BS-400 Clinical Chemistry Analyzer (Mindray, Shenzhen, China), respectively.

After sampling blood, mice were killed by cervical fracture. The heart, liver, spleen, kidney, thymus, and adipose tissues (parametrial plus peritoneal and perirenal adipose tissue) were quickly sampled and weighed. The liver tissues were stored at $-80^{\circ} \mathrm{C}$ until further analysis. The liver TG and TC concentrations were measured by the following method: $0.5 \mathrm{~g}$ of the liver tissue was homogenized in $4.5 \mathrm{~mL}$ of Krebs Ringer phosphate buffer ( $\mathrm{pH} 7.4$ ), then $0.2 \mathrm{~mL}$ of the homogenate was extracted with $4 \mathrm{~mL}$ chloroform/methanol $(2: 1, \mathrm{v} / \mathrm{v})$, the extract was concentrated under a nitrogen stream. The dry residue was analyzed using TG and TC test kits.

\section{Statistical Analysis}

The values were expressed as means \pm standard errors (SE). Statistical analysis was calculated by ANOVA using SPSS software (version 21). Scheffe's test was used to analyze the data. The criterion for statistical significance was $p<0.05$.

\section{RESULTS AND DISCUSSION}

\section{Characterization and Quantification of Saponins and Flavonoids in Adzuki Bean}

The HPLC results revealed the presence of flavonoids mainly in $45 \%$ ethanol fractions and the presence of saponins mainly in $80 \%$ ethanol fractions by $\mathrm{AB}-8$ resin column. It was reported that AB-8 resin was good at separating chemical constituent according to the polarity (Liu et al., 2010). After that, polyamide column was employed to further purify the flavonoids. Eluent of $40 \%$ ethanol from polyamide column was obtained, and the fraction was rich in flavonoids. Precipitation with methanolacetone was applied to further separate flavonoids and saponins from adzuki bean. Flavonoids existed in the supernatant fraction, while saponins presented in the precipitate fraction. Finally, ABTE, ABF, and ABS were obtained and utilized for HPLC-DADESI-MS $^{n}$ analysis. The detailed characterization of compounds in adzuki bean extract was presented in author thesis (Liu, 2014). The contents of saponins and flavonoids in adzuki bean extract were reported in our latest publication (Liu et al., 2017). Briefly, the contents of catechin $(49.4 \mathrm{mg} / \mathrm{g})$, quercetin-3-O-rutinoside (404.7 mg/g), quercetin-3-O-glucoside $(90.1 \mathrm{mg} / \mathrm{g})$, and vitexin$4^{\prime \prime}$-O-glucoside $(74.6 \mathrm{mg} / \mathrm{g})$ in $\mathrm{ABF}$ extract were much higher than that of the ABTE $(12.4,225.9,21.4$, and $36.7 \mathrm{mg} / \mathrm{g}$, respectively). Meanwhile, the contents of azukisaponin IV (11.4 mg/g), azukisaponin VI (206.3 mg/g), azukisaponin V (283.2 $\mathrm{mg} / \mathrm{g})$, azukisaponin II $(389.7 \mathrm{mg} / \mathrm{g})$, azukisaponin I $(5.4 \mathrm{mg} / \mathrm{g})$, and azukisaponin III $(27.6 \mathrm{mg} / \mathrm{g})$ in adzuki bean saponins extract were much higher than that of $\operatorname{ABTE}(6.6,20.0$, $165.9,186.9,8.9$, and $79.0 \mathrm{mg} / \mathrm{g}$, respectively).

\section{Effects of Adzuki Bean on $\alpha$-Glucosidase and Pancreatic Lipase Activities In Vitro}

$\alpha$-Glucosidase is a key enzyme to hydrolysis polysaccharides and disaccharides into glucose in small intestine (Vannasaeng et al.,
1995; Mooradian and Thurman, 1999; Scheen, 2003). Inhibition of $\alpha$-glucosidase activity can block digestion and absorption of carbohydrates, further control metabolism disorders such as diabetes and obesity; while pancreatic lipase is a key enzyme to catalyze the hydrolysis of dietary fat in the digestive system (Mukherjee, 2003), 50-70\% of the dietary fat can be hydrolyzed by this enzyme. Thus inhibition of pancreatic lipase activity can block fat absorption in gastrointestinal tract, further control obesity incidence, especially diet-induced obesity. The previous articles also reported that adzuki bean had the inhibitory effects on the two enzymes (Yao et al., 2011a,b; Sreerama et al., 2012). Yao et al. (2011b) tested $\alpha$-glucosidase activity of 16 food legumes, and the results showed that adzuki bean had the highest inhibition activity. Further study of different fractions of $70 \%$ ethanol extract of adzuki bean also exhibited inhibitory effects on $\alpha$-glucosidase. In the present study, total extract, flavonoids, and saponins from adzuki bean demonstrated inhibitory effects on both $\alpha$-glucosidase and pancreatic lipase.

Total extract, flavonoids, and saponins from adzuki bean demonstrated inhibitory effects on both $\alpha$-glucosidase and pancreatic lipase in dose-dependent manner at the concentration ranged from 0.25 to $1 \mathrm{mg} / \mathrm{mL}$ in the assay system using triolein emulsified with phosphatidylcholine (Table 1). ABF $(1 \mathrm{mg} / \mathrm{mL})$ exhibited the highest inhibitory rate of $\alpha$-glucosidase with $91.5 \%$, followed by saponin $(68.3 \%)$, and total extract $(55.7 \%)$. The inhibitory rates of $\alpha$-glucosidase were respectively much higher than $50 \%$ except for the ABTE at the concentration of $0.25 \mathrm{mg} / \mathrm{mL}$. With regard to pancreatic lipase activity, $\mathrm{ABTE}, \mathrm{ABF}$, and ABS exhibited the similar inhibitory rates (around 40\%).

TABLE 1 | Effect of adzuki bean on $\alpha$-glucosidase and pancreatic lipase activities.

\begin{tabular}{ccc}
\hline $\begin{array}{c}\text { Concentration of } \\
\text { samples }(\mathrm{mg} / \mathrm{mL})\end{array}$ & $\begin{array}{c}\alpha \text {-Glucosidase } \\
\text { inhibition (\%) }\end{array}$ & $\begin{array}{c}\text { Pancreatic lipase } \\
\text { inhibition (\%) }\end{array}$ \\
\hline $\begin{array}{c}\text { Control } \\
0\end{array}$ & $0 \pm 0^{\mathrm{a}}$ & $0 \pm 0^{\mathrm{a}}$ \\
ABTE & & \\
0.25 & $48.69 \pm 0.513^{\mathrm{b}}$ & $23.77 \pm 2.037^{\mathrm{b}}$ \\
0.50 & $50.67 \pm 0.443^{\mathrm{c}}$ & $29.25 \pm 2.673^{\mathrm{bc}}$ \\
0.75 & $52.74 \pm 0.208^{\mathrm{d}}$ & $36.40 \pm 1.777^{\mathrm{de}}$ \\
1.00 & $55.65 \pm 0.227^{\mathrm{e}}$ & $42.90 \pm 0.809^{\mathrm{e}}$ \\
ABF & & \\
0.25 & $81.74 \pm 0.201^{\mathrm{f}}$ & $38.63 \pm 2.215^{\mathrm{bc}}$ \\
0.50 & $87.09 \pm 0.387^{\mathrm{g}}$ & $29.34 \pm 1.625^{\mathrm{c}}$ \\
0.75 & $88.52 \pm 0.277^{\mathrm{g}}$ & $33.89 \pm 2.727^{\mathrm{de}}$ \\
1.00 & $91.84 \pm 0.288^{\mathrm{h}}$ & $39.65 \pm 1.161^{\mathrm{e}}$ \\
ABS & & \\
0.25 & $57.63 \pm 0.218^{\mathrm{i}}$ & $21.17 \pm 1.114^{\mathrm{b}}$ \\
0.50 & $62.84 \pm 0.254^{\mathrm{j}}$ & $25.07 \pm 1.163^{\mathrm{bc}}$ \\
0.75 & $67.50 \pm 0.599^{\mathrm{k}}$ & $39.83 \pm 1.214^{\mathrm{e}}$ \\
1.00 & $68.33 \pm 0.092^{\mathrm{k}}$ & $42.80 \pm 1.810^{\mathrm{e}}$ \\
\hline ABTE & &
\end{tabular}

$A B T E$, total extract of adzuki bean; $A B F$, flavonoids of adzuki bean; $A B S$, saponins of adzuki bean. Values are expressed as means $\pm S E$ of three experiments. Values marked by the same letters within column are not significantly different $(p<0.05)$. 
TABLE 2 | Effect of adzuki bean on noradrenaline-induced lipolysis in isolated fat cells from rats.

\begin{tabular}{lc}
\hline Treatments & $\begin{array}{c}\text { Lipolysis (\% of control) } \\
\text { Mean } \pm \text { SE }(\boldsymbol{n}=\mathbf{3})\end{array}$ \\
\hline None & $0 \pm 0^{\mathrm{a}}$ \\
Noradrenaline $(0.01 \mu \mathrm{g} / \mathrm{mL})$ & $100 \pm 0^{\mathrm{b}}$ \\
Noradrenaline + ABTE $(1 \mathrm{mg} / \mathrm{mL})$ & $166.08 \pm 4.094^{\text {ef }}$ \\
ABTE $(1 \mathrm{mg} / \mathrm{mL})$ & $136.84 \pm 7.542^{\mathrm{d}}$ \\
Noradrenaline + ABF $(1 \mathrm{mg} / \mathrm{mL})$ & $175.63 \pm 7.935^{\mathrm{f}}$ \\
ABF $(1 \mathrm{mg} / \mathrm{mL})$ & $112.87 \pm 3.094^{\mathrm{bc}}$ \\
Noradrenaline + ABS $(1 \mathrm{mg} / \mathrm{mL})$ & $152.63 \pm 5.916^{\mathrm{e}}$ \\
ABS $(1 \mathrm{mg} / \mathrm{mL})$ & $119.69 \pm 3.514^{\mathrm{c}}$ \\
\hline
\end{tabular}

ABTE, total extract of adzuki bean; $A B F$, flavonoids of adzuki bean; $A B S$, saponins of adzuki bean. Values are expressed as means $\pm S E$ of three experiments. Values marked by the same letters within column are not significantly different $(p<0.05)$.

\section{Effects of Adzuki Bean on Noradrenaline-Induced Lipolysis of Isolated Fat Cells from Rats}

Lipolysis assay was carried out in the present study according to the previous articles (Okuda et al., 1986; Han et al., 1999). The present article showed that ABTE, ABF, and ABS enhanced the noradrenaline-induced lipolysis $(166.1,175.6$, and $152.6 \%$, respectively) in the isolated fat cells at the concentration of $1 \mathrm{mg} / \mathrm{mL}$ (Table 2). While ABTE, ABF, and ABS without noradrenaline also enhanced lipolysis (136.8, 112.9, and 119.7\%, respectively) in the fat cells at the same concentration. In a word, ABTE, ABF, and ABS enhanced the noradrenaline-induced lipolysis in the isolated fat cells. It implied that adzuki bean could contribute to weight lose by breaking down fats.

\section{Effects of Adzuki Bean on Body Weight of Mice Fed with a High-Fat Diet for 8 Weeks}

In order to investigate the effects of adzuki bean on obesity in mice fed with HFD, body weight was recorded during the

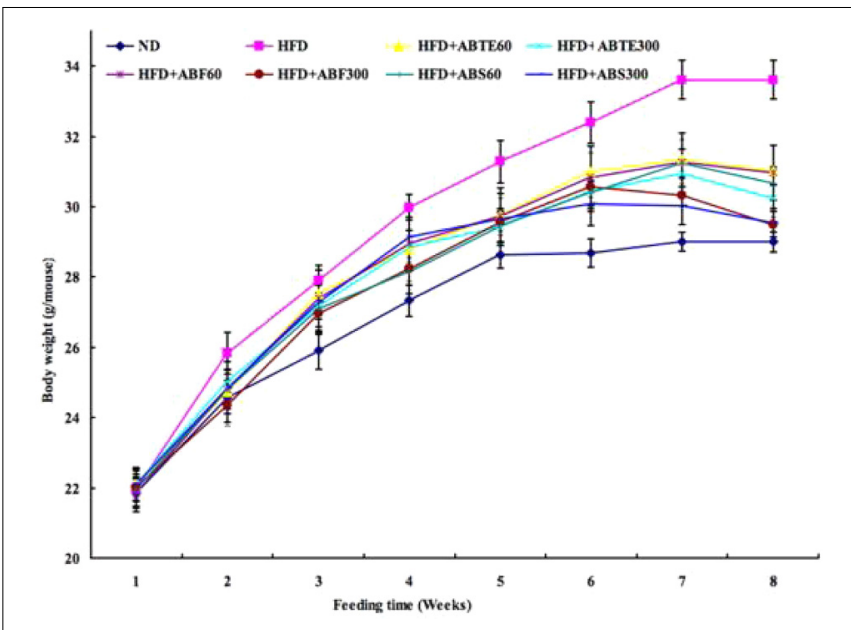

FIGURE 1 | Effect of adzuki bean on body weight of mice fed with a high-fat diet for 8 weeks. ND, normal diet group; HFD, high-fat diet group; HFD + ABTE60, HFD group orally administered total extract of adzuki bean of $60 \mathrm{mg} / \mathrm{kg}$ per day; HFD + ABTE300, HFD group orally administered total extract of adzuki bean of $300 \mathrm{mg} / \mathrm{kg}$ per day; HFD + ABF60, HFD group with ABF of $60 \mathrm{mg} / \mathrm{kg}$; HFD + ABF300, HFD group with ABF of $300 \mathrm{mg} / \mathrm{kg}$; $\mathrm{HFD}+\mathrm{ABS} 60$, HFD group with ABS of $60 \mathrm{mg} / \mathrm{kg} ; \mathrm{HFD}+\mathrm{ABS} 300$, HFD group with $A B S$ of $300 \mathrm{mg} / \mathrm{kg}$. Values are expressed as means $\pm \mathrm{SE}(n=8)$. Values marked by the same letters within final body weight are not significantly different $(p<0.05)$.

8 weeks and set to the first parameter to evaluate obesity. The kinetic changes of body weight of mice with different treatments during 8 weeks were presented in Figure 1. There was a whole increase trend of body weights; however, there were significant $(p<0.05)$ differences between the HFD group and other groups with or without treatment of ABTE, ABF, or ABS. After 8 weeks, HFD increased the body weights of HFD group mice from 21.96 to $33.61 \mathrm{~g}$, while body weights of ND group mice increased from 21.86 to $29.00 \mathrm{~g}$. Compared to the HFD group, ABTE treatments ( $300 \mathrm{mg} / \mathrm{kg}$ per day) significantly $(p<0.05)$ reduced the final body weight by $7.7 \%$, while ABTE

TABLE 3 | Effect of adzuki bean on organ weights of mice fed with a high-fat diet for 8 weeks.

\begin{tabular}{|c|c|c|c|c|c|}
\hline Groups & $\begin{array}{c}\text { Final body } \\
\text { weight (g/mouse) }\end{array}$ & $\begin{array}{l}\text { Thymus } \\
\text { (g/mouse) }\end{array}$ & $\begin{array}{c}\text { Liver } \\
\text { (g/mouse) }\end{array}$ & $\begin{array}{c}\text { Spleen } \\
\text { (g/mouse) }\end{array}$ & $\begin{array}{c}\text { Kidney } \\
\text { (g/mouse) }\end{array}$ \\
\hline ND & $29.00 \pm 0.284^{a}$ & $0.085 \pm 0.004^{b}$ & $1.156 \pm 0.056^{a}$ & $0.126 \pm 0.003^{a}$ & $0.296 \pm 0.009^{a}$ \\
\hline HFD & $33.61 \pm 0.544^{c}$ & $0.065 \pm 0.004^{a}$ & $1.947 \pm 0.097^{d}$ & $0.119 \pm 0.004^{a}$ & $0.336 \pm 0.013^{b}$ \\
\hline HFD + ABTE60 & $31.03 \pm 0.722^{a}$ & $0.067 \pm 0.004^{a}$ & $1.485 \pm 0.036^{c}$ & $0.121 \pm 0.008^{a}$ & $0.302 \pm 0.014^{a b}$ \\
\hline HFD + ABTE300 & $30.24 \pm 0.366^{a b}$ & $0.075 \pm 0.005^{a b}$ & $1.401 \pm 0.031^{b c}$ & $0.126 \pm 0.003^{a}$ & $0.304 \pm 0.013^{a b}$ \\
\hline $\mathrm{HFD}+\mathrm{ABF} 60$ & $30.97 \pm 0.779^{b}$ & $0.067 \pm 0.006^{a}$ & $1.238 \pm 0.018^{a}$ & $0.127 \pm 0.003^{a}$ & $0.292 \pm 0.009^{a}$ \\
\hline $\mathrm{HFD}+\mathrm{ABF} 300$ & $29.50 \pm 0.193^{a b}$ & $0.072 \pm 0.007^{a b}$ & $1.176 \pm 0.048^{a}$ & $0.123 \pm 0.005^{a}$ & $0.282 \pm 0.015^{a}$ \\
\hline HFD + ABS60 & $30.67 \pm 0.472^{b}$ & $0.068 \pm 0.009^{a b}$ & $1.317 \pm 0.054^{a b}$ & $0.123 \pm 0.007^{a}$ & $0.294 \pm 0.009^{a}$ \\
\hline $\mathrm{HFD}+\mathrm{ABS} 300$ & $29.55 \pm 0.406^{a b}$ & $0.070 \pm 0.004^{a b}$ & $1.162 \pm 0.030^{a}$ & $0.128 \pm 0.007^{a}$ & $0.279 \pm 0.010^{a}$ \\
\hline
\end{tabular}

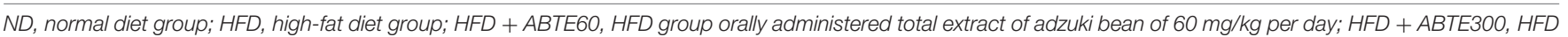

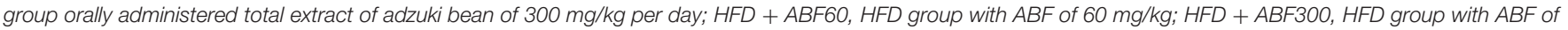

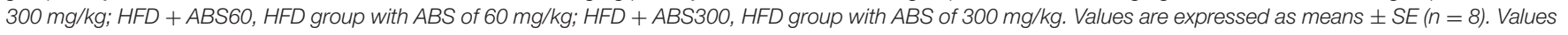
marked by the same letters within column are not significantly different $(p<0.05)$. 


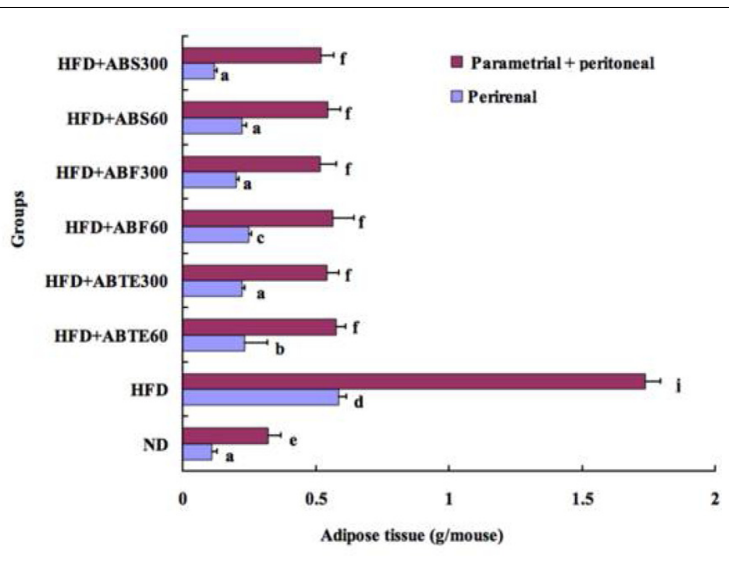

FIGURE 2 | Effect of adzuki bean on parametrial and perirenal adipose tissue weight of mice fed with a high-fat diet for 8 weeks. ND, normal diet group; HFD, high-fat diet group; HFD + ABTE60, HFD group orally administered total extract of adzuki bean of $60 \mathrm{mg} / \mathrm{kg}$ per day; HFD + ABTE300, HFD group orally administered total extract of adzuki bean of $300 \mathrm{mg} / \mathrm{kg}$ per day; $\mathrm{HFD}+\mathrm{ABF} 60$, HFD group with ABF of $60 \mathrm{mg} / \mathrm{kg}$; HFD + ABF300, HFD group with $\mathrm{ABF}$ of $300 \mathrm{mg} / \mathrm{kg}$; HFD + ABS60, HFD group with ABS of $60 \mathrm{mg} / \mathrm{kg}$; $\mathrm{HFD}+\mathrm{ABS} 300$, HFD group with ABS of $300 \mathrm{mg} / \mathrm{kg}$. Values are expressed as means $\pm \mathrm{SE}(n=8)$. Values marked by the same letters within parametrial or perirenal adipose tissue weight are not significantly different $(p<0.05)$.

treatments $(300 \mathrm{mg} / \mathrm{kg}$ per day) reduced the final body weight by $10.0 \%$. ABF and ABS treatments also revealed significant reduction of the final body weight as compared to the HFD group, especially $\mathrm{ABF}$ (300 $\mathrm{mg} / \mathrm{kg}$ per day) treatment with reduction of the final body weight by $12.2 \%$. ABTE, ABF, or ABS reduced the mice weights. Wu et al. (2011) reported that alcohol extract of adzuki bean reduced the body weight of male and female Kunming mice fed with a HFD, which supported our present results that adzuki bean could reduce body weight of ICR female mice fed with a HFD. Additionally, adzuki bean seed coats could significantly reduce body weight of streptozotocin-induced diabetic rats (Sato et al., 2005), while hot water extract of adzuki bean also could reduce body weights of rats (Itoh and Furuichi, 2009).

\section{Effects of Adzuki Bean on Organ Weight and Adipose Tissue Weight of Obese Mice}

Thymus weight, liver weight, spleen weight, and kidney weight of mice with different treatments were analyzed deliberatively after 8 weeks (Table 3). Adzuki bean treatments increased the thymus weight and decreased the liver weight as compared to the HFD group. The weight of spleen with or without adzuki bean treatment showed no differences in the present study. With regard to kidney, $\mathrm{ABTE}, \mathrm{ABF}$, and $\mathrm{ABS}$ could reduce kidney weight as compared to HFD group mice, and the ABF and ABS exhibited the better effect, the kidney weight in the mice treated with flavonoids and saponins were almost similar to that of ND group mice.

Body fat, especially abdominal fat, is harmful to human health. A previous article had reported that adzuki bean decreased adipose tissue weights in mice and rats (Wu et al., 2011). Our results verified the previous findings. The bar chat (Figure 2) compared perirenal and parametrial plus peritoneal adipose tissue weights among the mice groups with different treatments. Feeding a HFD for 8 weeks caused significant $(p<0.05)$ increases tissue weight in both perirenal and parametrial plus peritoneal adipose tissue as compared to the ND group. The perirenal and parametrial plus peritoneal adipose tissue weights of HFD group were 0.59 and $1.74 \mathrm{~g}$, respectively, while that of ND group were 0.11 and $0.32 \mathrm{~g}$. Adzuki bean treatment reduced significantly both perirenal and parametrial plus peritoneal adipose tissue weights as compared to the HFD group. It was an increase trend with the increased dose of ABTE, ABF, or ABS. Saponins treatment (300 mg/kg per day) demonstrated the best effect in terms of reducing perirenal and parametrial plus peritoneal adipose tissue weights. The perirenal and parametrial plus peritoneal adipose tissue weights of mice treated with ABS (300 mg/kg per day) were 0.12 and $0.52 \mathrm{~g}$, respectively.

TABLE 4 | Effect of adzuki bean on serum parameters and liver parameters after 8 weeks.

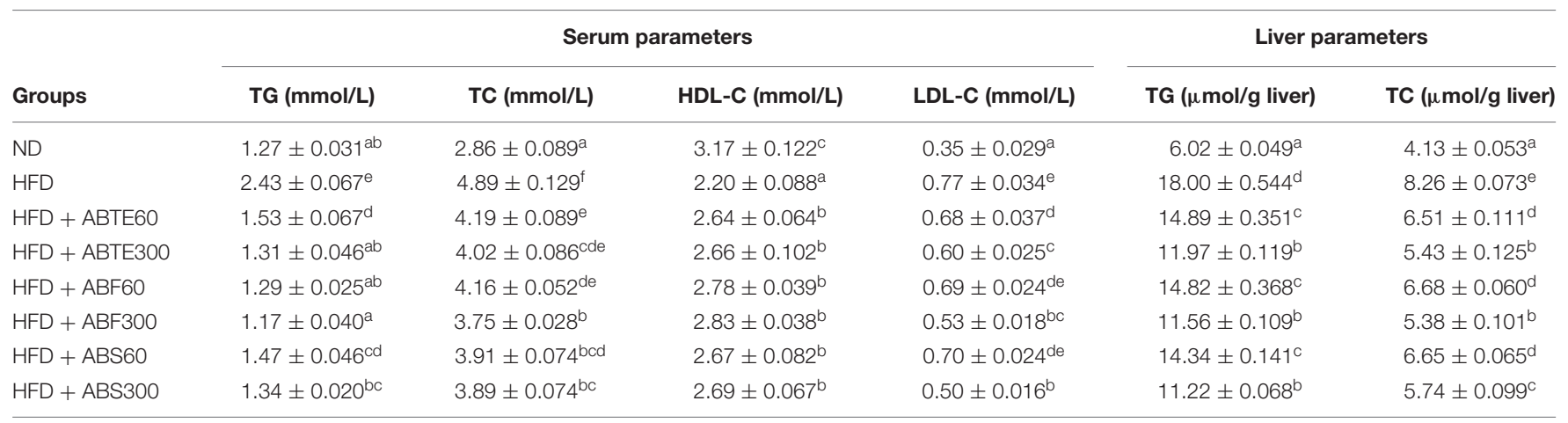

Values are expressed as means $\pm S E(n=8)$. Values marked by the same letters within column are not significantly different $(p<0.05)$. ND, normal diet group; HFD, high-fat diet group; HFD + ABTE60, HFD group orally administered total extract of adzuki bean of $60 \mathrm{mg} / \mathrm{kg}$ per day; HFD + ABTE300, HFD group orally administered total extract of adzuki bean of $300 \mathrm{mg} / \mathrm{kg}$ per day; HFD + ABF60, HFD group with ABF of $60 \mathrm{mg} / \mathrm{kg} ;$ HFD + ABF300, HFD group with ABF of $300 \mathrm{mg} / \mathrm{kg} ; \mathrm{HFD}+\mathrm{ABS60}$, HFD group with ABS of $60 \mathrm{mg} / \mathrm{kg}$; HFD + ABS300, HFD group with ABS of $300 \mathrm{mg} / \mathrm{kg}$; TG, triglycerides; TC, total cholesterol; HDL-C, high density lipoprotein-cholesterol. 


\section{Effects of Adzuki Bean on Biochemical Parameters of Serum and Liver of Obese Mice}

As the main risk factors for dyslipidemia (Klein, 2004), serum TC and TG was considered as unhealthy symbols of human body. In the present study, the HFD significantly $(p<0.05)$ induced fasting serum concentrations of serum TG, TC, and LDL-C, as compared to mice treated with the ND (Table 4). Adzuki bean treatment with the HFD suppressed the increases of serum TG, TC, and LDL-C concentrations as compared to the HFD group without adzuki bean treatment, while increased the level of HDL-C. The higher dose of adzuki bean samples, the more decreases in serum TG, TC, and LDL-C concentrations, while more increases in serum HDL-C. Wu et al. (2011) also pointed out that adzuki bean lowered blood TG and TC levels and increased HDL-C level of Kunming mice. Adzuki bean also decreased serum TC and TG levels of rats; however, it did not increase HDL-C level of rats (Itoh and Furuichi, 2009; KitanoOkada et al., 2012).

Feeding a HFD caused mice liver to accumulate higher content of TG (18.00 $\mu \mathrm{mol} / \mathrm{g}$ liver) and TC (8.26 $\mu \mathrm{mol} / \mathrm{g}$ liver) as compared to the ND group $(6.02 \mu \mathrm{mol} \mathrm{TG} / \mathrm{g}$ liver and $4.13 \mu \mathrm{mol}$ TC/g liver, respectively). The concentration of liver TG was about threefold higher than that of the normal group, while liver TC was over twofold higher than that of the normal group. Adzuki bean treatments, especially the high dose, retarded the accumulation of liver TG and TC, but did not recover to the normal level.

\section{CONCLUSION}

In summary, in vitro and in vivo anti-obesity effects of total extract, flavonoids, and saponins extracted from adzuki bean were respectively investigated in the present study. The results indicated that total extract, flavonoids, and saponins possessed the inhibitory effects against pancreatic lipase and $\alpha$-glucosidase, while flavonoids and saponins enhanced the noradrenalineinduced lipolysis in fat cells. The animal study also demonstrated the anti-obesity ability of these components. Our results showed that total extract, flavonoids, and saponins from adzuki bean

\section{REFERENCES}

Festi, D., Colecchia, A., Sacco, T., Bondi, M., Roda, E., and Marchesini, G. (2004). Hepatic steatosis in obese patients: clinical aspects and prognostic significance. Obesity Rev. 5, 333-334. doi: 10.1111/j.1467-789X.2004.00126.x

Han, L. K., Takaku, T., Li, J., Kimura, Y., and Okuda, H. (1999). Anti-obesity action of oolong tea. Int. J. Obesity 23, 98-105. doi: 10.1038/sj.ijo.0800766

Hill, J. O., Melanson, E. L., and Wyatt, H. T. (2000). Dietary fat intake and regulation of energy balance: implications for obesity. J. Nutr. 130, 284S-288S.

Itoh, T., and Furuichi, Y. (2009). Lowering serum cholesterol level by feeding a $40 \%$ ethanol-eluted fraction from HP-20 resin treated with hot water extract of adzuki beans (Vigna angularis) to rats fed a high-fat cholesterol diet. Nutrition 25, 318-321. doi: 10.1016/j.nut.2008.08.011

Itoh, T., Itoh, Y., Hibasami, H., Katsuzaki, H., Imai, K., Furuichi, Y., et al. (2005). Isolation of a substance inducing apoptosis of cultured human gastric cancer cells from a hot-water extract of adzuki (Vigna angularis). J. Japan Soc. Nutr. Food Sci. 58, 281-287. doi: 10.4327/jsnfs.58.281 could decrease body weight, adipose tissue weights, serum TG, TC, and LDL-C, and live lipids of mice fed with a HFD while increase serum HDL-C by orally administered method. The results of the present study indicate that adzuki bean is a potential important medicinal source for the prevention of obesity and the related diseases. The limitation of the current study was that the crude extracts were used, because there were no enough amounts of isolated and purified compounds from adzuki bean for animal study. Therefore, further studies should to be done in compounds isolation and be focus on the anti-obesity molecular mechanism of bioactive compounds from adzuki bean by cell models and the anti-obesity effects through clinical trials. In addition, new anti-obesity products derived from adzuki bean deserve to be developed in the future.

\section{AUTHOR CONTRIBUTIONS}

RL designed, carried out experiments and wrote the manuscript. YZ helped in animal feeding, dissection and carryout few biochemical assays. ZC designed, supervised, and corrected the manuscript. BX designed, wrote, and corrected the manuscript.

\section{FUNDING}

This project is supported by two UIC internal grants (Project Code: R201624 and R201714) from Beijing Normal UniversityHong Kong Baptist University United International College, China.

\section{ACKNOWLEDGMENTS}

Authors thank Prof. Jinming $\mathrm{Mu}$ in Faculty of Agronomy of Jilin Agricultural University for identifying adzuki bean and lab technicians in Animal Facility of Jilin Agricultural University. Author also acknowledge that Hong Kong Baptist University Library authorize the author to publish the part of data in open access thesis deposited (http://repository.hkbu.edu.hk/etd_ oa/102).

Itoh, T., Itoh, Y., Mizutani, M., Fujishiro, K., Furuichi, Y., Komiya, T., et al. (2002). A hot water extract of adzuki (Vigna angularis) induces apoptosis in cultured human stomach cancer cells. J. Japan Soc. Food Sci. Technol. 49, 339-344. doi: 10.3136/nskkk.49.339

Itoh, T., Kita, N., Kurokawa, Y., Kobayashi, M., Horio, F., and Furuichi, Y. (2004). Suppressive effect of a hot water extract of adzuki beans (Vigna angularis) on hyperglycemia after sucrose loading in mice and diabetic rats. Biosci. Biotechnol. Biochem. 68, 2421-2426. doi: 10.1271/bbb.68.2421

Itoh, T., Kobayashi, M., Horio, F., and Furuichi, Y. (2009). Hypoglycemic effect of hot-water extract of adzuki (Vigna angularis) in spontaneously diabetic KK-Ay mice. Nutrition 25, 134-141. doi: 10.1016/j.nut.2008.08.001

Jia, G., and Lu, X. (2008). Enrichment and purification of madecassoside and asiaticoside from Centella asiatica extracts with macroporous resins. J. Chromatogr. A 1193, 136-141. doi: 10.1016/j.chroma.2008.04.024

Kitano-Okada, T., Ito, A., Koide, A., Nakamura, Y., Han, K. H., Shimada, K., et al. (2012). Anti-obesity role of adzuki bean extract containing polyphenols: in vivo and in vitro effects. J. Sci. Food Agric. 92, 2644-2651. doi: 10.1002/jsfa.5680 
Klein, S. (2004). The case of visceral fat: argument for the defense. J. Clin. Invest. 113, 1530-1532. doi: 10.1172/JCI200422028

Kushner, R. F. (2002). Medical management of obesity. Semin. Gastrointest. Dis. 13, $123-132$.

Kwon, Y. I., Apostolidis, E., and Shetty, K. (2008). In vitro studies of eggplant (Solanum melongena) phenolics as inhibitors of key enzymes relevant for type 2 diabetes and hypertension. Bioresour. Technol. 99, 2981-2988. doi: 10.1016/j. biortech.2007.06.035

Liu, R. (2014). Anti-obesity Effects of Flavonoids and Saponins from Adzuki Bean. Ph.D. thesis, Hong Kong Baptist University, Kowloon Tong.

Liu, R., Cai, Z. W., and Xu, B. J. (2017). Characterization and quantification of flavonoids and saponins in adzuki bean (Vigna angularis L.) by HPLCDAD-ESI-MS $^{\mathrm{n}}$ analysis. Chem. Cent. J. 11:93. doi: 10.1186/S13065-017$0317-\mathrm{x}$

Liu, R., Zhang, J., Liu, W., Kimura, Y., and Zheng, Y. (2010). Anti-obesity effects of protopanaxdiol types of ginsenosides isolated from the leaves of American ginseng (Panax quinquefolius L.) in mice fed with a high-fat diet. Fitoterapia 81, 1079-1087. doi: 10.1016/j.fitote.2010.07.002

Mooradian, A. D., and Thurman, J. E. (1999). Drug therapy of postprandial hyperglycemia. Drugs 57, 19-29. doi: 10.2165/00003495-199957010-00003

Mukherjee, M. (2003). Human digestive and metabolic lipases-a brief review. J. Mol. Catal. B Enzym. 22, 369-376. doi: 10.1016/S1381-1177(03)00052-3

Nammi, S., Koka, S., Chinnala, K. M., and Boini, K. M. (2004). Obesity: an overview on its current perspectives and treatment options. Nutr. J. 3:3. doi: 10.1186/ 1475-2891-3-3

Okuda, H., Tsujita, T., and Kinutani, M. (1986). Studies on a protein kinase inhibitor-insensitive, phospholipase C-sensitive pathway of lipolysis in rat adipocytes. Pharmacol. Res. Commun. 18, 877-893. doi: 10.1016/0031-6989(86) 90093-7

Rodbell, M. (1964). Metabolism of isolated fat cells. J. Chem. Biol. 239, 375-380.

Sato, S., Yamate, J., Hori, Y., Hatai, A., Nozawa, M., and Sagai, M. (2005). Protective effect of polyphenol-containing adzuki bean (Vigna angularis) seed coats on the renal cortex in streptozotocin-induced diabetic rats. J. Nutr. Biochem. 16, 547-553. doi: 10.1016/j.jnutbio.2005.02.003

Scheen, A. J. (2003). Is there a role for alpha-glucosidase inhibitors in the prevention of type 2 diabetes mellitus? Drugs 63, 933-951.

Sreerama, Y. N., Takahashi, Y., and Yamaki, K. (2012). Phenolic antioxidants in some Vigna species of legumes and their distinct inhibitory effects on $\alpha$-glucosidase and pancreatic lipase activities. J. Food Sci. 77, 927-933. doi: 10.1111/j.1750-3841.2012.02848.x

Takahashi, S., Hori, K., Shinbo, M., Hiwatashi, K., Gotoh, T., and Yamada, S. (2008). Isolation of human renin inhibitor from soybean: soyasaponin I is the novel human renin inhibitor in soybean. Biosci. Biotechnol. Biochem. 72, 3232-3236. doi: $10.1271 /$ bbb. 80495

Tsujita, T., and Okuda, H. (1983). Carboxylesterases in rat and human sera and their relationship of serum aryl acylamidases and cholinesterases. Eur. J. Biochem. 133, 215-220. doi: 10.1111/j.1432-1033.1983.tb07450.x

Vannasaeng, S., Ploybutr, S., Nitiyanant, W., Peerapatdit, T., and Vichayanrat, A. (1995). Effects of alpha-glucosidase inhibitor (acarbose) combined with sulfonylurea or sulfonylurea and metformin in treatment of non-insulindependent diabetes mellitus. J. Med. Assoc. Thai. 78, 578-585.
Wei, Q., Dai, Y., Wu, Y., and Zhang, W. J. (2011). Study on enriching total flavonoids from Folium chrysanthemi with polyamide and macroporous resin. Zhong Yao Cai 34, 1285-1288.

WHO (2010). 10 Facts on Obesity. Available at: http://www.who.int/features/ factfiles/obesity/zh/index.html

Wu, B., Liu, X. R., Pu, S. J., Zhao, B., Wan, P., and Gao, J. M. (2011). Effect of adzuki beans alcohol extract on decreasing lipid and anti-obesity of the mice fed a high-fat diet. J. Chin. Inst. Food Sci. Technol. 11, 13-19.

Wu, X., Beecher, G. R., Holden, J. M., Haytowitz, D. B., Gebhardt, S. E., and Prior, R. L. (2004). Lipophilic and hydrophilic antioxidant capacities of common foods in the United States. J. Agric. Food Chem. 52, 4026-4037. doi: 10.1021/ jf049696w

Wu, X. R., Liu, Z. G., Yan, R. L., and Sun, W. F. (2009). Separation and purification of total flavonoids in Smilax glabra by polyamide resins. Zhong Yao Cai 32, 1606-1609.

Xu, B. J., and Chang, S. K. C. (2012). Comparative study on antiproliferation properties and cellular antioxidant activities of commonly consumed food legumes against nine human cancer cell lines. Food Chem. 134, 1287-1296. doi: 10.1016/j.foodchem.2012.02.212

Yao, Y., Cheng, X., Wang, L., Wang, S., and Ren, G. A. (2011a). Determination of potential $\alpha$-glucosidase inhibitors from adzuki beans (Vigna angularis). Int. J. Mol. Sci. 12, 6445-6451. doi: 10.3390/ijms 12106445

Yao, Y., Cheng, X., Wang, L., Wang, S., and Ren, G. (2011b). Biological potential of sixteen legumes in China. Int. J. Mol. Sci. 12, 7048-7058. doi: 10.3390/ ijms 12107048

Zapf, J., Schoenle, E., Waldvogel, M., Sand, I., and Froesch, E. R. (1981). Effect of trypsin treatment of rat adipocytes on biological effects and binding of insulin and insulin-like growth factors: further evidence for the action of insulin-like growth factors through the insulin receptor. Eur. J. Biochem. 113, 605-609. doi: $10.1111 /$ j.1432-1033.1981.tb05105.x

Zha, L. Y., Mao, L. M., Lu, X. C., Deng, H., Ye, J. F., Chu, X. W., et al. (2011). Anti-inflammatory effect of soyasaponins through suppressing nitric oxide production in LPS-stimulated RAW 264.7 cells by attenuation of NF-kB-mediated nitric oxide synthesis expression. Bioorg. Med. Chem. Lett. 21, 2415-2418. doi: 10.1016/j.bmcl.2011.02.071

Zhang, W., and Popovich, D. G. (2010). Group B oleanane triterpenoid extract containing soyasaponins I and III from soy flour induces apoptosis in HepG2 cells. J. Agric. Food Chem. 58, 5315-5319. doi: 10.1021/jf90 37979

Conflict of Interest Statement: The authors declare that the research was conducted in the absence of any commercial or financial relationships that could be construed as a potential conflict of interest.

Copyright $\odot 2017$ Liu, Zheng, Cai and Xu. This is an open-access article distributed under the terms of the Creative Commons Attribution License (CC BY). The use, distribution or reproduction in other forums is permitted, provided the original author(s) or licensor are credited and that the original publication in this journal is cited, in accordance with accepted academic practice. No use, distribution or reproduction is permitted which does not comply with these terms. 